\title{
Proteolytic activity of dairy lactic acid bacteria and probiotics as determinant of growth and in vitro angiotensin-converting enzyme inhibitory activity in fermented milk
}

\author{
Osaana N. DONKOR ${ }^{\mathrm{a}}$, Anders HENRIKSSON ${ }^{\mathrm{b}}$, Todor VASILJEVIC ${ }^{\mathrm{a}}$, \\ Nagendra P. SHAH ${ }^{*}$ \\ a School of Molecular Sciences, Victoria University, Werribee Campus, P.O. Box 14428, Melbourne, \\ Vic 8001, Australia \\ b DSM Food Specialties Australia Pty Ltd, P.O. Box 83, Moorebank, NSW 1875, Australia
}

Received 5 June 2006 - Accepted 29 November 2006

\begin{abstract}
Two strains each of Lactobacillus acidophilus (L10 and La 4962), Bifidobacterium spp. (B. lactis B94 and B. longum B1 536), and Lactobacillus casei (L26 and Lc 279), and one strain each of Streptococcus thermophilus (St 1342) and Lactobacillus delbrueckii ssp. bulgaricus (Lb 1466) were assessed for growth characteristics, proteolytic activity and release of in vitro angiotensin-converting enzyme inhibitory peptides in reconstituted skim milk. Single cultures grew well with exception of Lactobacillus delbrueckii ssp. bulgaricus. Despite slow growth, this culture produced substantial amount of lactic acid, second to $S$. thermophilus. All strains exhibited proteolytic activities with intra- and extracellular specific peptidases including X-prolyl-dipeptidyl aminopeptidase. The latter cleaved proline-containing sequences, which possibly enhanced liberation of various peptides and likely resulted in improved cell growth. The extent of proteolysis varied among strains and appeared to be time dependant. All the cultures released peptides with in vitro ACE-inhibitory activity during growth with B. longum $\mathrm{Bl} 536$ and L. acidophilus $\mathrm{L} 10$ having $\mathrm{IC}_{50}$ values of 0.196 and $0.151 \mathrm{mg} \cdot \mathrm{mL}^{-1}$, respectively.
\end{abstract}

dairy culture / probiotics / proteolytic activity / growth / angiotensin-converting enzyme inhibition (ACE-I)

摘要 - 乳酸菌和益生菌在乳基培养基和发酵乳制品中的生长特性及产生的生物活性肽研 究。本文研究了两株嗜酸乳杆菌 (L10, La 4962), 两株双歧杆菌 (B. lactis B94, B. longum Bl 536), 两株干酪乳杆菌 (L26, Lc 279), 一株嗜执链球菌 (St 1342) 和一株德氏乳杆菌保加利 亚亚种 (Lb 1466) 在还原脱脂乳中的生长特性、蛋白水解酶的活性以及具有抑制血管紧缩素 转移酶 (ACE) 活性的生物活性肽的释放。除了德氏乳杆菌保加利亚亚种外, 所有的菌株在 乳基培养基中的生长性能良好, 尽管这株菌在乳基培养基中的生长速度较慢, 但却能够产 生大量的乳酸, 其产乳酸的量仅次于嗜热链球菌。所有的菌株均能分泌出具有蛋白水解活 性的胞内和胞外肽酶, 如 X-脯氨酰 - 二肽酰基 - 氨基肽酶。该酶能够选择性地众肽的 $\mathrm{N}$ 端 水解含有脯氨酸的肽链, 释放出小分子的肽, 而这些小分子肽进一步促进了细胞的生长。 各菌株的蛋白水解程度不同, 并且每菌株的蛋白水解活性随着培养时间的增加而提高。所 有菌株在发酵乳中均产生能够抑制血管紧缩素转移酶活性的生物活性肽。其中长双歧杆菌 B1 536 和嗜酸乳杆菌 L10 产生的这种生物活性肽的活性最高, 其 $\mathrm{IC}_{50}$ 值分别为 0.196 和 $0.151 \mathrm{mg} \cdot \mathrm{mL}^{-1}$ 。

乳基培养基 / 益生菌 / 蛋白水解活力 / 生长特性 / 血管紧缩素转移酶抑制作用

* Corresponding author (通讯作者): Nagendra.Shah@vu.edu.au 
Résumé - L'activité protéolytique des bactéries lactiques et probiotiques laitiers détermine la croissance et l'activité inhibitrice de l'enzyme de conversion de l'angiotensine (ACE) dans le lait fermenté. Deux souches de Lactobacillus acidophilus (L10 et La 4962), de Bifidobacterium spp. (B. lactis B94 et B. longum B1 536), et de Lactobacillus casei (L26 et Lc 279), et une souche de Streptococcus thermophilus (St 1342) et de Lactobacillus delbrueckii ssp. bulgaricus (Lb 1466) ont été étudiées pour leurs caractéristiques de croissance, activité protéolytique et libération de peptides inhibant l'ACE in vitro dans du lait écrémé reconstitué. Les cultures pures croissaient bien à l'exception de Lactobacillus delbrueckii ssp. bulgaricus. Malgré une croissance lente, cette culture produisait des quantités substantielles d'acide lactique, venant en seconde position après $S$. thermophilus. Toutes les souches présentaient des activités protéolytiques avec des peptidases intra- et extracellulaires dont une X-prolyl-dipeptidyl aminopeptidase. Cette enzyme coupait les séquences contenant une proline, ce qui améliorait potentiellement la libération de peptides variés et, en conséquence, probablement la croissance cellulaire. L'importance de la protéolyse était variable selon les souches, mais apparaissait dépendante du temps. Toutes les cultures libéraient des peptides ayant une activité inhibitrice de l'ACE in vitro au cours de la croissance, avec pour B. longum et $L$. acidophilus $\mathrm{L} 10$ des valeurs d' $\mathrm{IC}_{50}$ de 0,196 et de $0,151 \mathrm{mg} \cdot \mathrm{mL}^{-1}$ respectivement.

bactérie lactique / probiotique / activité protéolytique / croissance / activité inhibitrice de l'ACE

\section{INTRODUCTION}

Incorporation of probiotic organisms such as Lactobacillus acidophilus, Bifidobacterium spp., and $L$. casei in fermented dairy products provides a potential to improve health status of consumers. A growing public awareness of diet related health issues and mounting evidence regarding health benefits of probiotics have increased consumers demand for foods containing probiotic organisms. Probiotics are defined by the Food and Agricultural Organization of the United Nations (FAO) and World Health Organization (WHO) as "live microorganisms, which when administered in adequate amounts confer a health benefit on the host" [14]. A number of health benefits of probiotic organisms has been suggested and described in numerous reviews [25, 37].

However, certain criteria during production of probiotic foods need to be satisfied to ensure maximization of therapeutic properties of probiotics. These include the incorporation of sufficient numbers of probiotic microorganisms into the product, maintenance of viable populations during shelf life of the food and subsequent survival of these organisms through the gastrointestinal tract (GIT) [32, 51]. Fermented dairy foods present ideal delivery systems for probiotics to the human GIT, since they may provide a favourable environment, which promotes growth and enhances viability of these organisms [25]. On the other hand, several factors such as low $\mathrm{pH}$, presence of hydrogen peroxide and dissolved oxygen as well as the state of culturing and storage conditions may affect the survival of probiotic bacteria in fermented dairy products [36, 38, 44].

Lactic acid bacteria (LAB) including probiotic organisms are fastidious in nature, requiring numerous essential growth factors. Milk, although a rich growth medium, contains low concentration of free amino acids and peptides to efficiently support growth of LAB $[39,48]$. In response to this limitation, LAB have developed a complex system of proteinases and peptidases, which enable them to utilise casein as an additional source of organic nitrogen [41]. On the other hand, Klaver et al. [20] reported that Bifidobacterium strains were not as proteolytic as other LAB. This may explain why Bifidobacterium spp. grows slowly in milk and may require supplementation of peptides and amino acids from external sources [11].

The proteolytic activities of LAB including yoghurt starter bacteria and probiotic organisms have been studied extensively and proteolytic enzymes have been isolated and characterised $[22,39,50]$. Such an interest has been derived from the importance of 
proteolytic system of LAB in cheese ripening and rapid growth in milk during fermentation as well as improved survival during storage [12]. This ability of dairy LAB and probiotics has become even more important upon realising that a range of bioactive peptides may be liberated due to microbial action. Biologically active peptides are generated during milk fermentation by proteolytic enzymes produced by various LAB such as L. helveticus, L. lactis subsp. cremoris FT4 and L. delbrueckii ssp. bulgaricus SS1 [18, 27]. These biologically active peptides include hypotensive peptides which inhibit angiotensin I-converting enzyme (ACE), opioid agonist and antagonist peptides, and mineral binding, immunomodulatory, antibacterial, and antithrombotic peptides [30,35]. Angiotensin I-converting enzyme regulates blood pressure via formation of vasopressor angiotensin II from angiotensin I [40]. Inhibition of ACE mainly results in an overall hypotensive effect. High proteolytic activity is expected to promote good cell growth and ACE-inhibitory activity in fermented milk.

As stated, the proteolytic activity of dairy cultures is very important governing factor playing a major role in various cellular and physiological processes. Therefore, the aims of our study were to assess the proteolytic activity of selected dairy lactic acid bacteria and probiotic organisms as determinant of growth and in vitro ACE inhibitory activity in fermented milk.

\section{MATERIALS AND METHODS}

\subsection{Bacterial cultures}

L. acidophilus LAFTI $^{\circledR}$ L10, B. lactis LAFTI $^{\circledR}$ B94 and L. casei LAFTI $^{\circledR}$ L26 were obtained from DSM Food Specialties (Moorebank, NSW, Australia) and have been reported to have probiotic properties [8]. S. thermophilus St 1342, L. delbrueckii subsp. bulgaricus Lb 1466, L. acidophilus La 4962, B. longum Bl 536 and L. casei Lc 279 were supplied by the Victoria University Culture Collection (Werribee, Australia). Each strain was propagated in de Mann Rogosa Sharpe (MRS) broth (Oxoid,
West Heidelberg, Australia) at $37^{\circ} \mathrm{C}$ with the exception of L. delbrueckii ssp. bulgaricus $\mathrm{Lb} 1466$ which was propagated at $42{ }^{\circ} \mathrm{C}$. For propagation of Bifidobacterium, sterile MRS broth was supplemented with $0.05 \%$ L-cysteine-hydrochloride to provide anaerobic condition and stimulate their growth [29]. After three successive transfers of $20 \mathrm{~h}$ incubation each, the activated organisms were used for the preparation of the pre-inocula for further experiments. The pre-inocula were prepared by transferring $1 \%(\mathrm{v} / \mathrm{v})$ of activated culture to $10 \mathrm{~mL}$ aliquots of reconstituted skim milk (RSM) supplemented with $2 \%$ glucose and $1 \%$ yeast extract.

\subsection{Proteolytic systems of LAB}

\subsubsection{Preparation of intracellular and cell wall extracts}

Individual cultures of $L$. acidophilus L10, Bifidobacterium B94, L. casei L26, S. thermophilus St 1342, L. delbrueckii ssp. bulgaricus Lb 1466, L. acidophilus La 4962, Bifidobacterium B1 536 and L. casei Lc 279 were propagated three successive times in RSM and finally in MRS broth according to the methods previously reported $[39,50]$. The latter was performed to prevent a carryover of milk proteins and their interference with the assay. Thus after two subculturing in MRS medium for $18 \mathrm{~h}$ at $37^{\circ} \mathrm{C}$, cultures were cultivated separately in $100 \mathrm{~mL}$ batches of MRS broth at $42{ }^{\circ} \mathrm{C}$. The cells were then harvested by centrifugation at $4000 \times g$ at $4{ }^{\circ} \mathrm{C}$ for $30 \mathrm{~min}$ at the end of the logarithmic growth phase at approximately $20 \mathrm{~h}$ which was determined by measuring the absorbance at $600 \mathrm{~nm}$. The supernatant was designated as the cell-free extracellular enzymatic extract (EE). The cell pellet obtained was washed twice with $0.9 \%(\mathrm{w} / \mathrm{v}) \mathrm{NaCl}$ solution and resuspended in $10 \%$ volume of original growth medium with $0.05 \mathrm{M}$ Tris-HCl buffer, $\mathrm{pH}$ 8.5. The resulting cell dispersion was sonicated for $5 \mathrm{~min}$ at $30 \mathrm{~s}$ intervals at $4{ }^{\circ} \mathrm{C}$. The supernatant obtained after centrifugation at $4000 \times g$ for $30 \mathrm{~min}$ at $4{ }^{\circ} \mathrm{C}$ was designated as the intracellular enzymatic extract (IE). 


\subsubsection{Determination of protein concentration}

The protein content of the EE and IE extracts was estimated using the method of Bradford [3]. A 0.1-mL aliquot of the enzyme solution and $3-\mathrm{mL}$ aliquot of the Bradford reagent (Sigma) were vortexed gently to mix thoroughly and the samples were incubated at room temperature for 30 min after which the absorbance was measured at $595 \mathrm{~nm}$. Bovine serum albumin (Sigma) was used as a standard. The protein concentration of the samples was determined by comparing the net absorbance values obtained at $595 \mathrm{~nm}$ against the standard curve.

\subsubsection{Enzyme assay}

Endopeptidase and tripeptidase activities of the EE and IE extracts were detected by thin-layer chromatography (TLC) according to the method of Shihata and Shah [39] and Tan and Konings [45] with some modifications. Each reaction mixture contained $60 \mu \mathrm{L}$ of a $2 \mu \mathrm{mmol} \cdot \mathrm{L}^{-1}$ substrate (Gly-Ala-Tyr, Gly-Leu-Phe and Bradykinin) in $20 \mathrm{mmol} \cdot \mathrm{L}^{-1}$ Tris- $\mathrm{HCl} \mathrm{pH} 7.0$ and $20 \mu \mathrm{L}$ of extract. The reaction mixture was incubated for $60 \mathrm{~min}$ at $37^{\circ} \mathrm{C}$ and was stopped by adding $10 \mu \mathrm{L}$ of $30 \%$ acetic acid and cooling to $4{ }^{\circ} \mathrm{C}$. Ten microlitres of the mixture were spotted onto a precoated silica gel 60 plate $(50 \times 100 \times 0.25) \mathrm{mm}$ (Alltech Associates Pty. Ltd., Baulkham Hills, Australia). A 4:1:1 (v/v/v) mixture of $n$-butanol:acetic acid:water was used as the mobile phase. As a control, $2 \mathrm{mmol} \cdot \mathrm{L}^{-1}$ of each standard peptide was also spotted onto the plate. Silica gels were stained by spraying with $0.1 \%(w / v)$ ninhydrin in $99 \%$ ethanol. Peptides and amino acids became visible after incubating the plate in an oven for $5 \mathrm{~min}$ at $80{ }^{\circ} \mathrm{C}$.

The proteolytic strains of probiotic and yoghurt bacteria were assessed for selected peptidolytic activities using Pro-Ile, LeuTyr, Leu-Gly, Ala-Met, and Ala-His as well as Gly-Ala-Tyr, Gly-Leu-Phe and bradykinin as substrates according to the method of Shihata and Shah [39] and Wohlrab and Bockelmann [50]. The reaction mixture contained $10 \mu \mathrm{L}$ of enzyme solution, $424 \mu \mathrm{L}$ of $50 \mathrm{mmol} \cdot \mathrm{L}^{-1}$ Tris- $\mathrm{HCl} \mathrm{pH} 7.5,50 \mu \mathrm{L}$ of
$22 \mathrm{mmol} \cdot \mathrm{L}^{-1}$ substrate, $25 \mu \mathrm{L}$ of peroxidase $\left(5 \mathrm{mg} \cdot \mathrm{mL}^{-1}\right.$ in $\left.0.8 \mathrm{~mol} \cdot \mathrm{L}^{-1}\left(\mathrm{NH}_{4}\right)_{2} \mathrm{SO}_{4}\right)$, $25 \mu \mathrm{l}$ of L-amino acid oxidase $\left(2 \mathrm{mg} \cdot \mathrm{mL}^{-1}\right.$ in distilled water) and $25 \mu \mathrm{L}$ of $o$-dianisidine $\left(11.5 \mathrm{mmol} \cdot \mathrm{L}^{-1}\right)$. The reaction mixture was incubated at $50{ }^{\circ} \mathrm{C}$ for $20 \mathrm{~min}$ and was stopped by the addition of $50 \mu \mathrm{L}$ of dithiothreitol $\left(120 \mathrm{mmol} \cdot \mathrm{L}^{-1}\right)$. Oxidation of $o$-dianisidine coupled to substrate hydrolysis resulted in an increase in brown colour which was measured at $436 \mathrm{~nm}$. Enzyme activity was calculated using a molar absorbance coefficient of $8100 \mathrm{~mol}^{-1} \cdot \mathrm{cm}^{-1}$ and defined as the amount of enzyme required to oxidise $1 \mu \mathrm{mol}$ of $o$-dianisidine per min under assay conditions [50]. The specific activity was expressed as units per milligram of protein.

\subsubsection{Assessment of X-prolyl-dipepti- dyl aminopeptidase activity}

X-prolyl-dipeptidyl aminopeptidase (PepX) activity of dairy cultures is a very important characteristic due to high proline content in milk protein. This activity was assayed as described previously [29] with glycyl-prolyl $p$-nitroanilide (Sigma) (Gly-Pro-pNA) as the substrate with some modifications. The incubation mixture contained $50 \mu \mathrm{L}$ of $6.4 \mathrm{mmol} \cdot \mathrm{L}^{-1}$ of substrate, $2.85 \mathrm{~mL}$ of $50 \mathrm{mmol} \cdot \mathrm{L}^{-1}$ Tris- $\mathrm{HCl}$ buffer $\mathrm{pH} 7.0$, and $100 \mu \mathrm{L}$ of cell-free intracellular extract (IE) in $50 \mathrm{mmol} \cdot \mathrm{L}^{-1}$ Tris-HCl buffer $\mathrm{pH}$ 7.0. The mixture was incubated at $37^{\circ} \mathrm{C}$ for $20 \mathrm{~min}$ and the reaction was stopped by adding $500 \mu \mathrm{L}$ of $30 \%$ acetic acid. The extent of hydrolysis was measured with the Cary IE UV/visible spectrophotometer (Varian Australia Pty. Ltd., Melbourne, Australia) at $410 \mathrm{~nm}$. The same experiment was also performed with cell-free extracellular (EE) enzymatic extracts. One unit of enzyme activity was defined as the amount of enzyme required to release $1 \mu \mathrm{mol}$ of $p$ nitroanilide per min under assay conditions. The enzyme activity reported is expressed as specific PepX activity defined as units of enzyme activity per milligram of proteins. A unit of activity is derived from the enzyme content required to liberate $1 \mu \mathrm{mol}$ of $p$-nitroanilide per min under assay conditions. 


\subsection{Preparation of fermented milk}

Individually activated cultures of $L . a c$ idophilus (L10 and La 4962), Bifidobacterium spp. (B. lactis B94 and B. longum B1 536), L. casei (L26 and Lc 279), S. thermophilus (St 1342) and L. delbrueckii ssp. bulgaricus ( $\mathrm{Lb} 1466$ ) in the form of pre-inoculate (Sect. 2.1) were used for milk fermentations. Each organism was transferred into sterile RSM (12\%) to obtain approximately $10^{8}$ colony forming units (CFU) per $\mathrm{mL}$. The inoculated milk was incubated at $37{ }^{\circ} \mathrm{C}$ for $20 \mathrm{~h}$, and this step was repeated twice to prevent any carry overs (i.e. yeast extract) that would likely interfere with the assays [23]. Batch fermentations were further carried out with each culture in $12 \%$ (w/w) RSM. Eight batches of $250 \mathrm{~mL}$ aliquots of RSM were aseptically prepared with $1 \%(\mathrm{v} / \mathrm{v})$ of each of the cultures and incubated at $42{ }^{\circ} \mathrm{C}$ for $24 \mathrm{~h}$. The fermentation experiments were performed in triplicate. A control consisted of uninoculated RSM. During fermentation, aliquots of each batch were taken at $0,3,6,9,12$ and $24 \mathrm{~h}$ to monitor cell growth, organic acid production and $\mathrm{pH}$ changes. Proteolysis was monitored at $0,6,12$ and $24 \mathrm{~h}$.

\subsection{Cell growth}

The methods of Leclerc et al. [23] and Ravula and Shah [32] were used to assess the cell growth. One gram of each batch, aseptically sampled at $0,3,6,9$, and $24 \mathrm{~h}$, was 10 -fold serially diluted $\left(10^{3}\right.$ to $\left.10^{7}\right)$ in $0.15 \%$ sterile peptone (Oxoid) and water diluent. Enumeration of the bacteria was performed on MRS agar (Amyl media, Dandenong, Australia) using the pour plate technique as described previously [10,47]. Anaerobic jars and gas generating kits (Anaerobic system BR 38, Oxoid Ltd., Hampshire, England) were used for creating anaerobic conditions. Plates in duplicate were incubated for $48 \mathrm{~h}$ at $37^{\circ} \mathrm{C}$ for $L$. acidophilus, L. casei, and Bifidobacterium spp., $48 \mathrm{~h}$ at $42^{\circ} \mathrm{C}$ for $L$. delbrueckii ssp. bulgaricus and aerobically for $48 \mathrm{~h}$ at $37^{\circ} \mathrm{C}$ for $S$. thermophilus. All enumeration techniques followed protocols reported previously $[10,47]$. Plates with $25-250$ colonies were counted and recorded as CFU. $\mathrm{mL}^{-1}$ of the fermented milk. The $\mathrm{pH}$ changes of batches were monitored before and during fermentation at $0,3,6,9,12$ and $24 \mathrm{~h}$ using a pH meter (HANNA Instruments 8417, Singapore).

\subsection{Organic acids}

Organic acid contents were measured following the method of Shah and Ravula [38] with some modifications. Three millilitre aliquots of fermented milk were mixed with $50 \mu \mathrm{L}$ of $15.5 \mathrm{~mol} \cdot \mathrm{L}^{-1}$ nitric acid and then diluted with $1.0 \mathrm{~mL}$ of $0.01 \mathrm{~mol} \cdot \mathrm{L}^{-1}$ $\mathrm{H}_{2} \mathrm{SO}_{4}$ solution. The resulting mixture was centrifuged for $30 \mathrm{~min}$ at $14000 \times \mathrm{g}$ using an Eppendorf centrifuge (Model 5415C, Crown Scientific, Melbourne, Australia) to precipitate the protein. The supernatant was filtered through a $0.20-\mu \mathrm{m}$ membrane filter (FP point, Schleicher \& Schuell, Dassel, Germany) into an HPLC vial for the determination of organic acids. The separation of organic acids was achieved using a Varian HPLC (Varian Analytical Instruments, CA, USA) fitted with an Aminex HPX - 87H, $300 \times 7.8 \mathrm{~mm}$ ion exchange column (Biorad Life Science Group, Hercules, CA, USA) and a guard column maintained at $65^{\circ} \mathrm{C}$. Using $0.01 \mathrm{~mol} \cdot \mathrm{L}^{-1} \mathrm{H}_{2} \mathrm{SO}_{4}$ as the mobile phase, the flow rate was maintained at $0.6 \mathrm{~mL} \cdot \mathrm{min}^{-1}$. A UV/visible detector was used at $220 \mathrm{~nm}$. A $25-\mu \mathrm{L}$ injection volume was used for both samples and standards with the retention time of $12.15(\mathrm{~L}(+)$-lactic acid) and 14.40 (glacial acetic acid) min. Quantification of acetic and lactic acids was performed as described previously [13].

\subsection{Proteolytic activity in fermented milk}

The degree of proteolysis during fermentation of milk was determined by measuring the release of free $\mathrm{NH}_{3}$ groups following the $o$-phthaldialdehyde (OPA) method [6, 12]. An aliquot of $2.5 \mathrm{~mL}$ from each medium was mixed with $5 \mathrm{~mL}$ of $0.75 \%$ trichloroacetic acid (TCA) and the mixture was filtered using Advantec 231 filter (M.F.S. Inc., Dublin, CA, USA). The filtrate $(150 \mu \mathrm{L})$ was added to $3 \mathrm{~mL}$ of OPA reagent and after $2 \mathrm{~min}$ at room temperature 
$\left(20{ }^{\circ} \mathrm{C}\right)$, absorbance of the solution was measured by a spectrophotometer (LKB NOVASPEC II Pharmacia, LKB Biochrom, England) at $340 \mathrm{~nm}$. The proteolytic activity of these bacterial cultures was expressed as the absorbance of free amino groups measured at $340 \mathrm{~nm}$. A relative degree of proteolysis was determined as the difference between proteolytic activity in fermented milk to that of unfermented milk. All the analyses were carried out in triplicate.

\subsection{In vitro inhibition of angiotensin I-converting enzyme (ACE inhibitory activity)}

ACE inhibitory activity was measured according to Cushman and Cheung [9] with some modifications as described previously [13]. Briefly, $20 \mathrm{~g}$ of fermented milk were mixed with $5 \mathrm{~mL}$ of $0.75 \%$ TCA and the mixture was centrifuged at $4000 \times g$ for 30 min at $4{ }^{\circ} \mathrm{C}$. The $\mathrm{pH}$ of the supernatant was adjusted to 8.3 and $20 \mu \mathrm{L}$ of the filtrate was added to an aliquot of $200 \mu \mathrm{L}$ hippurylhistidyl-leucine (Sigma) dissolved in sodium borate buffer of $\mathrm{pH}$ 8.5. Aliquot of $60 \mu \mathrm{L}$ of the buffer was added to the mixture to maintain the $\mathrm{pH}$ of the reaction solution in the range between 8.1 and 8.3 [49]. The reaction was initiated by adding $20 \mu \mathrm{L}$ of ACE solution followed by incubation at $37^{\circ} \mathrm{C}$ for $30 \mathrm{~min}$. The reaction was stopped by adding $250 \mu \mathrm{L}$ of $1 \mathrm{~mol} \cdot \mathrm{L}^{-1} \mathrm{HCl}$ and $1.7 \mathrm{~mL}$ of ethyl acetate. The ethyl acetate layer (1.4 mL) was evaporated to dryness and the residue containing hippuric acid was dissolved in $1 \mathrm{~mL}$ of deionised water. The experimental procedure was repeated with unfermented RSM as a control prepared following the procedures as described above (appropriate MRS transfer into sterile RSM supplemented with yeast extract, followed by subsequent transfers and dilutions in RSM). The absorbance of the solution was measured spectrophotometrically using Cary IE UV/visible spectrophotometer (Varian) at $228 \mathrm{~nm}$ against water as a blank. The extent of inhibition was calculated as follows:

ACE-inhibitor activity $(\%)=1-\left[\frac{C-D}{A-B}\right] \times 100$ where $A=$ absorbance in the presence of $\mathrm{ACE}$ and the buffer only;

$B=$ absorbance in the presence of buffer only;

$C=$ absorbance in the presence of ACE, ACE-inhibitory component and the buffer;

$D=$ absorbance in the presence of ACEinhibitory component and the buffer.

Additionally ACE inhibition was expressed as an $\mathrm{IC}_{50}$, defined as the amount of sample required to inhibit $50 \%$ of the original ACE activity. The $\mathrm{IC}_{50}$ was determined using graphical extrapolation by plotting ACE inhibition as a function of different sample concentrations with known protein contents. All the analyses were carried out in triplicate.

\subsection{Statistical analysis}

The experiment was independently replicated three times in a completely randomized design. All results obtained were analysed as a split plot in time design with strains and time as main factors, using the general linear model (GLM) procedure of the SAS System [34]. The univariate ANOVA test was validated by fulfilling Huynh-Feldt (H-F) condition [24]. Where appropriate, one-way ANOVA and correlational analyses were employed and the multicomparison of means was assessed by Tukey's test. The statistical level of significance was preset at $0.05(P<0.05)$.

\section{RESULTS AND DISCUSSION}

\subsection{Assessment of extracellular and intracellular peptidase activity}

Table I shows the activities of extracellular and intracellular peptidases towards various peptides detected by TLC. All dairy cultures tested appeared to have produced enzymes capable of hydrolysing large biologically active peptide, bradykinin, at both the extracellular and intracellular levels. The enzymes involved in the hydrolysis may include endopeptidases PepE and $\mathrm{PepO}$ and aminopeptidase PepP [5]. PepE 
Table I. Aminopeptidase activities of single cultures: S. thermophilus St 1342, L. belbrueckii subsp. bulgaricus Lb 1466, L. acidophilus (L10 and La 4962), B. lactis B94, B. longum Bl 536, L. casei (L26 and Lc 279).

\begin{tabular}{lcc}
\hline \multirow{2}{*}{ Substrates } & \multicolumn{2}{c}{ Aminopeptidase activity } \\
\cline { 2 - 3 } & EE & IE \\
\hline Tripeptides & + & + \\
Gly-Ala-Tyr & + & + \\
Gly-Leu-Phe & - & + \\
\hline Oligopeptide & & + \\
Bradykinin & + &
\end{tabular}

Hydrolysis of peptides was analysed by TLC; $+=$ hydrolysis; $-=$ no hydrolysis; $\mathrm{EE}=$ cell wall extract; IE = intracellular extract.

has been identified to hydrolyse the N-terminal and C-terminal blocked substrate $\mathrm{N}$ benzoyl-Phe-Val-Arg-pNA [15]. PepE is capable of hydrolysing bradykinin (ArgPro-Pro-Gly-Phe-Ser-Pro-Phe-Arg) at the Gly4-Phe5 bond [5]. Similarly, PepO hydrolysis oligopeptides ranging in length from five to thirty-five including bradykinin [43]. Furthermore, PepP liberates the N-terminal amino acid from peptides with general specificity for Xaa-Pro-Pro-(Yaa)n sequences with high activity reported for peptides ranging from three to nine residues (i.e. bradykinin) but did not hydrolyse dipeptides [26]. Identified tripeptidase, PepT, has been reported to show no activity for any di-, tetra-, or larger oligopeptides and therefore exhibit strict specificity for tripeptides [5]. Consequently, the tripeptide substrates Gly-Ala-Tyr and Gly-Leu-Phe tested might have been hydrolysed by PepT. In addition to PepT, aminopeptidases PepC and PepP have also been reported to hydrolyse a variety of tripeptides with uncharged or basic residues in the amino acid terminal position [5]. However, with the substrate ending with a C-terminal of phenylalanine, Gly-Leu-Phe, the hydrolysis only occurred intracellularly, suggesting the location of these aminopeptidases. This was consistent with the findings of Shihata and Shah [39] and Tan and Konings [45]. The intracellular aminopeptidases are capa- ble of cleaving N-terminal amino acids from a wide range of peptides differing both in size and composition to release amino acids and peptides [21].

Specific tripeptidase and endopeptidase activities of yoghurt culture and selected strains of probiotic organisms assessed towards Gly-Ala-Tyr, Gly-Leu-Phe and oligopeptide bradykinin as substrates is shown in Table II. As opposed to other strains, the hydrolysis of all oligopeptides by L. acidophilus La 4962 was significantly $(P<0.05)$ higher at the IE level. This suggested that L. acidophilus La 4962 may have produced substantial amounts of PepT and PepE than the other strains which caused the hydrolysis of Gly-Ala-Tyr, Gly-Leu-Phe and oligopeptide bradykinin. Eventhough, all organisms showed specific tripeptidase activity mainly at the IE level, the extent of which was greatly $(P<0.05)$ strain specific confirmed previous reports (Tab. II) $[21,45,46]$. The low $(P<0.05)$ EE level of enzyme activity shows that tripeptidase and endopeptidase activities may solely take place intracellularly. The observed extracellular enzyme activity may be due to cell lysis and release of intracellular enzymes into the medium $[2,7]$. The EE values may further indicate variations in the extent of lysis which may be high with some cultures and likely lead to erroneous conclusions [2].

X-prolyl-dipeptidyl aminopeptidase, PepX, activity of cell-free extract of individual cultures of bacteria is presented in Figure 1. This enzyme is of great importance for the selection of dairy cultures due to high proline content in caseins. All the studied strains exhibited PepX activity towards glycyl-prolyl $p$-nitroanilide (GlyPro-pNA) as substrate at both IE and EE cell-free extracts. The IE level of X-prolyldipeptidyl aminopeptidase activity was significantly $(P<0.05)$ higher than that at the EE level. This shows that proline-containing peptides were mainly hydrolysed intracellularly by the enzyme (Fig. 1). Kunji et al. [21] reported the presence of PepX in all species of LAB. Pan et al. [29] similarly identified X-prolyl-dipeptidyl aminopeptidase activity from IE cell-free extract of L. helveticus in the hydrolysis of skimmed 
Table II. Tripeptidase specific activity of yoghurt culture and selected strains of probiotic organisms after $20 \mathrm{~h}$ of single culture fermentation in MRS at $42{ }^{\circ} \mathrm{C}$.

\begin{tabular}{|c|c|c|c|}
\hline \multirow{3}{*}{ Culture } & \multicolumn{3}{|c|}{ Tripeptidase specific activity, $\mathrm{U} \cdot \mathrm{mg}^{-1}$ protein } \\
\hline & \multicolumn{3}{|c|}{ Substrates } \\
\hline & Gly-Ala-Tyr & Bradykinin & Gly-Leu-Phe \\
\hline \multicolumn{4}{|c|}{ S. thermophilus St 1342} \\
\hline $\mathrm{EE}$ & $370.79 \pm 1.14^{\mathrm{a}}$ & $349.32 \pm 0.38^{b}$ & $359.97 \pm 0.72^{c}$ \\
\hline IE & $555.09 \pm 0.40^{\mathrm{a}}$ & $534.32 \pm 0.70^{b}$ & $551.30 \pm 0.91^{\mathrm{c}}$ \\
\hline
\end{tabular}

L. delbrueckii ssp.

bulgaricus Lb 1466

$\begin{array}{llll}\text { EE } & 441.06 \pm 6.91^{\mathrm{a}} & 500.88 \pm 0.96^{\mathrm{b}} & 449.36 \pm 0.46^{\mathrm{a}} \\ \text { IE } & 770.45 \pm 0.42^{\mathrm{a}} & 671.99 \pm 1.57^{\mathrm{b}} & 700.76 \pm 1.52^{\mathrm{c}}\end{array}$

L. acidophilus L10

$\begin{array}{llll}\text { EE } & 218.20 \pm 2.30^{\mathrm{Aa}} & 246.80 \pm 0.51^{\mathrm{Ab}} & 252.11 \pm 0.51^{\mathrm{Ab}} \\ \mathrm{IE} & 557.47 \pm 0.46^{\mathrm{Aa}} & 521.10 \pm 1.18^{\mathrm{Ab}} & 485.40 \pm 1.66^{\mathrm{Ac}}\end{array}$

L. acidophilus La 4962

EE

IE

$704.52 \pm 32.73^{\mathrm{aB}}$

$611.14 \pm 7.76^{\mathrm{Bab}}$

$675.21 \pm 0.29 \mathrm{Bc}$

$2844.43 \pm 3.45^{\mathrm{aB}}$

$2921.26 \pm 2.84^{\mathrm{Bb}}$

$3021.52 \pm 1.13^{\mathrm{Bc}}$

\section{B. lactis B94}

$\mathrm{EE}$

IE

$671.96 \pm 3.63 \mathrm{Aa}$

$180.72 \pm 1.46^{\mathrm{Ab}}$

$1360.36 \pm 3.12^{\mathrm{Ab}}$

$209.78 \pm 2.81^{\mathrm{Ac}}$

$1516.73 \pm 9.44 \mathrm{Aa}$

$628.39 \pm 2.57^{\mathrm{Ba}}$

$656.43 \pm 2.08^{\mathrm{Bb}}$

$741.68 \pm 0.34 \mathrm{Bb}$

$583.77 \pm 2.19^{\mathrm{Bc}}$

$724.69 \pm 0.91^{\mathrm{Bc}}$

IE

L. casei $\mathrm{L} 26$

EE

$289.78 \pm 2.74 \mathrm{Aa}$

$414.14 \pm 4.20^{\mathrm{Ab}}$

$726.36 \pm 2.11^{\mathrm{Ac}}$

IE

$899.92 \pm 1.05 \mathrm{Aa}$

$907.47 \pm 9.60^{\mathrm{Aab}}$

$927.82 \pm 0.23^{\mathrm{Ab}}$

L. casei Lc 279

\begin{tabular}{llll}
$\mathrm{EE}$ & $470.76 \pm 29.51^{\mathrm{Ba}}$ & $573.84 \pm 23.27^{\mathrm{Ba}}$ & $467.94 \pm 49.42^{\mathrm{Ba}}$ \\
$\mathrm{IE}$ & $646.27 \pm 0.80^{\mathrm{Ba}}$ & $644.55 \pm 0.32^{\mathrm{Ba}}$ & $652.03 \pm 0.64^{\mathrm{Bb}}$ \\
\hline
\end{tabular}

Results presented as a mean of three observations. Significant when $P<0.05$; tripeptidase activity expressed as specific activity defined as units of enzyme activity per milligram of protein in crude cellular extract.

$\mathrm{EE}=$ extracellular cell wall extract; $\mathrm{IE}=$ intracellular extract.

abc Means in the same row with different small letter superscripts are significantly different;

$\mathrm{AB}$ means in the same column for particular strains with different capital letter superscripts are significantly different. 


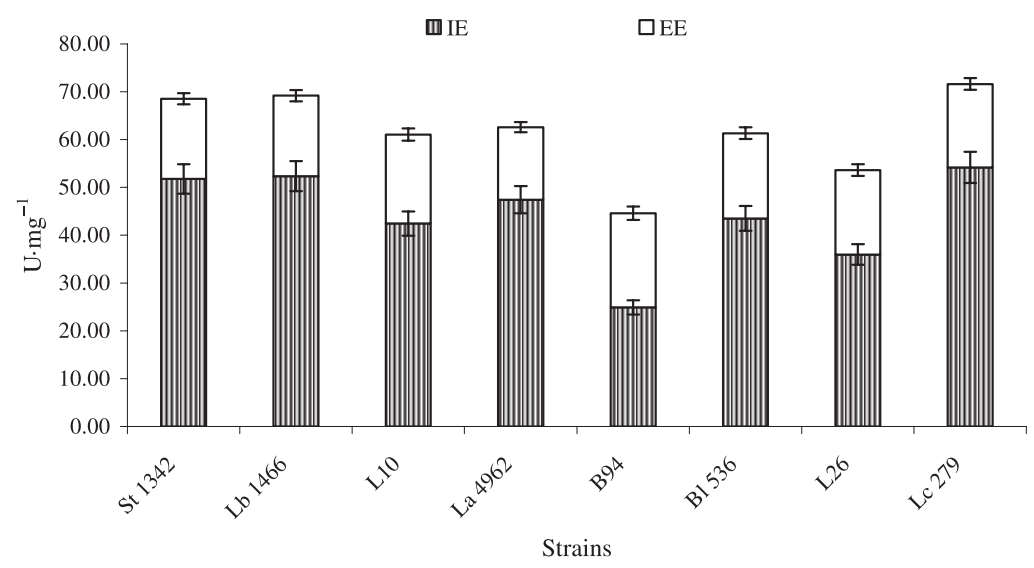

Figure 1. X-prolyl-dipeptidyl aminopeptidase activity of cell-free intracellular(IE) and extracellular (EE) enzymatic extracts of individual cultures of bacteria (S. thermophilus St 1342, L. delbrueckii subsp. bulgaricus Lb 1466, L. acidophilus L10, B. lactis B94 and L. casei L26, L. acidophilus La 4962, B. longum Bl 536 and $L$. casei Lc 279) using Gly-Pro-pNA as the substrate in $50 \mathrm{mmol} \cdot \mathrm{L}^{-1}$ Tris-HCl buffer $\mathrm{pH} 7.0$ at $37^{\circ} \mathrm{C}$. Aminopeptidase specific activity is defined as units (U) of enzyme activity per $\mathrm{mg}$ of protein in crude cellular extract. One unit of enzyme activity was defined as the amount of enzyme required to release $1 \mu \mathrm{mol}$ of $p$-nitroanilide per min under assay conditions (Error bars represent a pooled standard error of the mean).

milk proteins. Fernandez-Espla et al. [16] detected the presence of various prolinespecific peptidases in the cell-free extract of L. casei ssp. case $i$ IFPL 731 and further reported that the enzyme usually cleaves $\mathrm{N}$ terminal X-Pro dipeptides from tri- and oligopeptides. The aminopeptidase activities of microorganisms included in our study may contribute to the production of free amino acids in a fermenting medium as growth factors and peptides, which may have ACE-inhibitory activity [29].

Aminopeptidase activities of all examined strains towards dipeptide substrates are shown in Table III. The strains studied exhibited on average $71 \%$ dipeptidases activity at the IE level showing preference towards N-terminal hydrophobic/uncharged residues resulting in hydrolysis of free amino acids for growth. Leu-Gly, Leu-Tyr, Ala-Met and Ala-His were probably hydrolysed by either one or both aminopeptidases (PepC and PepN) of the studied microorganisms. These enzymes, which have been identified in LAB, were reported to exhibit broad specificity for residues that are basic, acidic, hydrophobic/uncharged and aromatic substrates [5]. Wohlrab and Bockelmann [50] also observed that all dipeptidases were active towards numerous dipeptides. PepC and PepN, on the other hand, have been shown to be inactive towards Pro-Xaa dipeptides [5]. Since PepX has specificity for removal of proline-containing dipeptides (X-Pro $\downarrow$ Y...) from the N-termini of peptides [5], it may be assumed that PepX was likely not active towards Pro-Ile. Therefore the probable presence of aminopeptidase PepR in the studied strains might have hydrolysed the tested substrate Pro-Ile from the hydrophobic uncharged Cterminal-Ile. In general, all the organisms showed appreciable aminopeptidase activity at the IE level towards Ala-Met, Leu-Tyr, Leu-Gly, Ala-His, and Pro-Ile, in accordance with the findings of Shihata and Shah [39]. Contrary to our findings, Tan et al. [46] observed very low or no intracellular dipeptidase activity towards Pro-containing dipeptides. Extracellular dipeptidase activity observed in our study was significantly $(P<0.05)$ lower for all substrates than that at the IE level. Bifidobacterium spp. showed 
Table III. Dipeptidase specific activities of single strains of selected probiotic organisms and yoghurt culture after $20 \mathrm{~h}$ of individual fermentations in MRS at $42^{\circ} \mathrm{C}$.

\begin{tabular}{|c|c|c|c|c|c|}
\hline \multirow{3}{*}{ Culture } & \multicolumn{5}{|c|}{ Dipeptidase specific activity, $\mathrm{U} \cdot \mathrm{mg}^{-1}$ protein } \\
\hline & & & Substrates & & \\
\hline & Leu-Gly & Leu-Tyr & Pro-Ile & Ala-Met & Ala-His \\
\hline \multicolumn{6}{|c|}{ S. thermophilus } \\
\hline \multicolumn{6}{|l|}{ St 1342} \\
\hline $\mathrm{EE}$ & $90.69 \pm 10.78^{a}$ & $82.20 \pm 22.34^{\mathrm{a}}$ & $71.58 \pm 0.30^{\mathrm{a}}$ & $92.81 \pm 14.56^{\mathrm{a}}$ & $93.72 \pm 17.36^{\mathrm{a}}$ \\
\hline IE & $271.35 \pm 0.99^{a}$ & $329.20 \pm 4.36^{b}$ & $317.26 \pm 0.64^{b}$ & $283.51 \pm 2.01^{\mathrm{a}}$ & $283.05 \pm 1.89^{\mathrm{a}}$ \\
\hline \multicolumn{6}{|c|}{$\begin{array}{l}\text { L. delbrueckii ssp. } \\
\text { bulgaricus }\end{array}$} \\
\hline \multicolumn{6}{|l|}{ Lb 1466} \\
\hline $\mathrm{EE}$ & $101.94 \pm 15.08^{\mathrm{a}}$ & $84.68 \pm 4.17^{\mathrm{a}}$ & $89.75 \pm 30.13^{\mathrm{a}}$ & $72.76 \pm 33.07 \mathrm{a}$ & $76.63 \pm 27.36^{\mathrm{a}}$ \\
\hline IE & $265.66 \pm 4.62^{\mathrm{a}}$ & $282.77 \pm 1.31^{\mathrm{ab}}$ & $281.17 \pm 2.48^{\mathrm{a}}$ & $239.77 \pm 2.99 \mathrm{bc}$ & $335.36 \pm 3.53^{\mathrm{bcd}}$ \\
\hline \multicolumn{6}{|c|}{ L. acidophilus } \\
\hline \multicolumn{6}{|l|}{ L10 } \\
\hline $\mathrm{EE}$ & $81.36 \pm 5.52^{\mathrm{Aa}}$ & $105.17 \pm 16.29 \mathrm{Aa}$ & $131.99 \pm 1.38^{\mathrm{Aa}}$ & $86.79 \pm 20.34^{\mathrm{Aa}}$ & $114.81 \pm 15.37 \mathrm{Aa}$ \\
\hline IE & $323.73 \pm 2.99 \mathrm{Aa}$ & $234.27 \pm 2.99 \mathrm{Ab}$ & $247.54 \pm 5.39 \mathrm{Ab}$ & $318.95 \pm 2.04 \mathrm{Aa}$ & $292.01 \pm 1.27 \mathrm{Abc}$ \\
\hline \multicolumn{6}{|c|}{ L. acidophilus } \\
\hline \multicolumn{6}{|l|}{ La 4962} \\
\hline $\mathrm{EE}$ & $241.78 \pm 35.50^{\mathrm{Ba}}$ & $297.55 \pm 5.04 \mathrm{Ba}$ & $270.50 \pm 43.51^{\mathrm{Ba}}$ & $277.85 \pm 25.38^{\mathrm{Ba}}$ & $207.38 \pm 28.73^{\mathrm{Ba}}$ \\
\hline IE & $1127.62 \pm 4.69^{\mathrm{Ba}}$ & $1097.02 \pm 2.84 \mathrm{Ba}$ & $1028.01 \pm 6.41^{\mathrm{Bb}}$ & $1081.39 \pm 17.91^{\mathrm{Ba}}$ & $917.33 \pm 5.33^{\mathrm{Bbc}}$ \\
\hline \multicolumn{6}{|l|}{ B. lactis } \\
\hline \multicolumn{6}{|l|}{ B94 } \\
\hline $\mathrm{EE}$ & $114.99 \pm 17.53^{\mathrm{Aa}}$ & $56.25 \pm 4.23^{\mathrm{Aa}}$ & $122.18 \pm 27.87^{\mathrm{Aa}}$ & $107.80 \pm 32.97 \mathrm{Aa}$ & $86.56 \pm 18.95^{\mathrm{Aa}}$ \\
\hline IE & $407.80 \pm 4.13^{\mathrm{Aa}}$ & $469.81 \pm 4.01 \mathrm{Ab}$ & $578.82 \pm 6.89^{A b c}$ & $518.18 \pm 3.59^{\mathrm{Abcd}}$ & $385.31 \pm 2.36^{\mathrm{Aa}}$ \\
\hline \multicolumn{6}{|c|}{ B. longum } \\
\hline \multicolumn{6}{|l|}{ B1 536} \\
\hline $\mathrm{EE}$ & $103.41 \pm 32.51^{\mathrm{Aa}}$ & $60.19 \pm 20.80^{\mathrm{Aa}}$ & $129.68 \pm 28.28 \mathrm{Aa}$ & $129.35 \pm 25.96^{\mathrm{Aa}}$ & $66.17 \pm 22.87 \mathrm{Aa}$ \\
\hline IE & $340.20 \pm 4.47^{\mathrm{Ba}}$ & $362.34 \pm 5.40^{\mathrm{Ba}}$ & $320.63 \pm 2.89^{\mathrm{Bab}}$ & $355.82 \pm 5.08 \mathrm{Ba}$ & $311.36 \pm 12.19^{\mathrm{Bab}}$ \\
\hline \multicolumn{6}{|l|}{ L. casei } \\
\hline \multicolumn{6}{|l|}{ L26 } \\
\hline $\mathrm{EE}$ & $124.17 \pm 3.53^{\mathrm{Aa}}$ & $64.73 \pm 6.38^{\mathrm{Aa}}$ & $87.76 \pm 15.02^{\mathrm{Aa}}$ & $101.14 \pm 5.18^{\mathrm{Aa}}$ & $67.53 \pm 30.21^{\mathrm{Aa}}$ \\
\hline IE & $417.04 \pm 14.67 \mathrm{Aa}$ & $277.57 \pm 1.87 \mathrm{Ab}$ & $280.31 \pm 0.82^{\mathrm{Ab}}$ & $307.98 \pm 1.19 \mathrm{Ab}$ & $313.01 \pm 8.77 \mathrm{Ab}$ \\
\hline \multicolumn{6}{|l|}{ L. casei } \\
\hline \multicolumn{6}{|l|}{ Lc 279} \\
\hline $\mathrm{EE}$ & $63.50 \pm 33.45^{\mathrm{Ba}}$ & $106.71 \pm 18.19 \mathrm{Ba}$ & $92.63 \pm 19.45^{\mathrm{Aa}}$ & $91.32 \pm 2.47 \mathrm{Aa}$ & $78.23 \pm 0.87 \mathrm{Aa}$ \\
\hline IE & $243.10 \pm 0.61 \mathrm{Ba}$ & $290.32 \pm 1.74 \mathrm{Ab}$ & $292.04 \pm 0.98 \mathrm{Ab}$ & $288.61 \pm 2.45^{\mathrm{Ab}}$ & $286.15 \pm 2.33 \mathrm{Ab}$ \\
\hline
\end{tabular}

Results presented as a mean of three observations. Significant when $P<0.05$; dipeptidase activity expressed as specific activity which is defined as units of enzyme activity per milligram of protein in crude cellular extract.

$\mathrm{EE}=$ extracellular cell wall extract; $\mathrm{IE}=$ intracellular extract.

abcd Means in the same row with different small letter superscripts are significantly different;

$\mathrm{AB}$ means in the same column for particular strains with different capital letter superscripts are significantly different. 


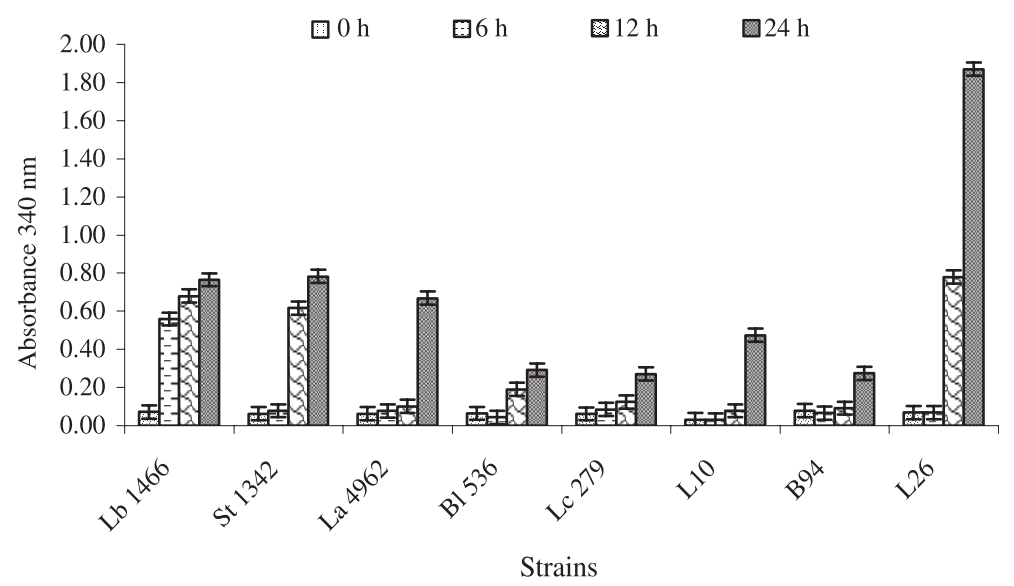

Figure 2. Proteolytic activity by single strains of bacteria (S. thermophilus St 1342, L. delbrueckii subsp. bulgaricus Lb 1466, L. acidophilus L10, B. lactis B94 and L. casei L26, L. acidophilus La 4962, B. longum Bl 536 and L. casei Lc 279) during $24 \mathrm{~h}$ fermentation in RSM at $42{ }^{\circ} \mathrm{C}$ (Error bars represent a pooled standard error of the mean $S E M=0.03$ absorbance units).

similarities in their intracellular dipeptidase activities, however, B. lactis B94 exhibited higher Pro-Ile and Ala-Met hydrolysis than that of B. longum Bl 536 (Tab. III). This may explain the similarity in their growth pattern (Fig. 3). Several studies [21, 45, 46] have reported dipeptidase activity solely at the IE level. It is interesting to note that there is little information available in the literature on aminopeptidase activities of $\mathrm{Bi}$ fidobacterium spp. Therefore this study is important in this area of enzyme activity and further work in understanding their proteolytic activity and growth in milk is underway.

\subsection{Proteolytic activity}

After analysing segments of proteolytic system in the defined medium, we assessed the proteolytic activities of selected LAB in RSM as presented in Figure 2. During fermentation, milk proteins were hydrolysed by LAB proteinases and peptidases resulting in an enhanced amount of free amino groups and peptides (Fig. 2). Juillard et al. [19] reported that the level of free amino acids and peptides in milk is low therefore LAB depend on a proteolytic system that allows for an efficient degradation of milk proteins. The presence of aminopeptidases is important for the release of amino acids for growth by microorganisms through the hydrolysis of peptides in the growth medium. Christensen and Steele [4] demonstrated that the loss of selected aminopeptidase (PepC, PepN, and PepX) activities resulted in significant impairment of growth rate in milk.

The extent of proteolysis varied among strains and appeared to be time dependant. As depicted in Figure 2, the amount of liberated amino groups and peptides increased only slightly during fermentation from 0 to $12 \mathrm{~h}$ for some strains (L. acidophilus L10, L. acidophilus $\mathrm{La}$ 4962, B. lactis B94, B. longum B1 536, L. casei L26, and L. casei Lc 279) but increased significantly $(P<0.05)$ for all strains from 12 to $24 \mathrm{~h}$ (Fig. 2). These findings were consistent with those reported by Nielsen et al. [28]. In contrast, however, Leclerc et al. [23] reported a linear increase in the amount of free amino groups until end of fermentation in milk fermented with L. helveticus strains. The proteolytic pattern certainly had a strong effect on bacterial growth due to correlation between these parameters, which ranged from 0.76 for L26 to 0.90 for St 1342. This dependence could possibly 


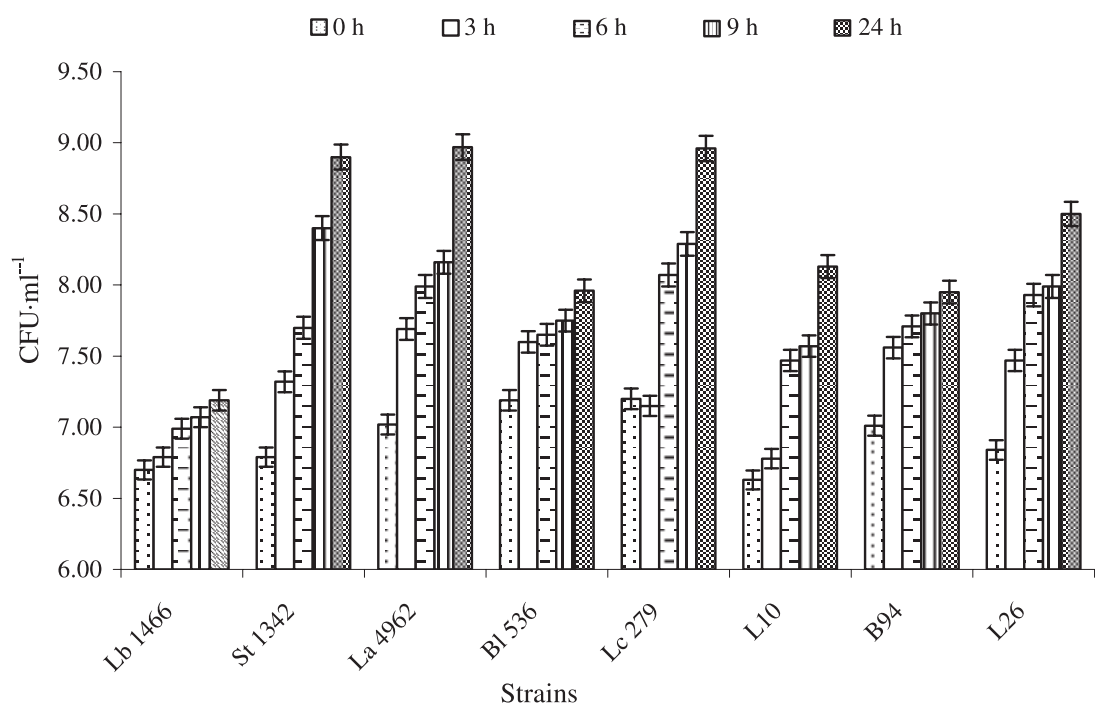

Figure 3. The change of cell concentration of selected dairy LAB and probiotic organisms (S. thermophilus St 1342, L. delbrueckii subsp. bulgaricus Lb 1466, L. acidophilus L10, B. lactis B94 and L. casei L26, L. acidophilus La 4962, B. longum Bl 536 and L. casei Lc 279) cultivated in reconstituted skim milk (RSM) for $24 \mathrm{~h}$ at $42{ }^{\circ} \mathrm{C}$ (Error bars represent a pooled standard error of the mean, $\left.\mathrm{SEM}=0.11 \mathrm{CFU} \cdot \mathrm{mL}^{-1}\right)$

explain the general slow cell growth up to $6 \mathrm{~h}$ of fermentation at $42^{\circ} \mathrm{C}$ [12]. Although L. delbrueckii ssp. bulgaricus Lb 1466 showed appreciable peptidase activity, it experienced poor growth. This indicated that this organism might require some other growth factors in addition to free amino acids and peptides. Lactobacillus casei L26 showed the highest proteolytic activity followed in order by L. delbrueckii ssp. bulgaricus Lb 1466, S. thermophilus St 1342 and L. acidophilus (La 4962 and L10), Bifidobacterium and L. casei (Lc 279) (Fig. 2) with the activity apparently strain specific $(P<0.0001)$. Similar to our findings, those of Shihata and Shah [39], Fuglsang et al. [17] also showed that the amount of free amino groups formed in the medium during fermentation was strain dependent. Thus, the differences in the amounts of amino groups released during fermentation of milk observed for the microorganisms, could probably relate to the different proteinases of the strains. Shihata and Shah [39] reported proteolytic activity of $S$. thermophilus, L. delbrueckii ssp. bulgaricus, and L. acidophilus to be much greater than that of Bifidobacterium spp. The results in our study also showed similar pattern of proteolytic activity for S. thermophilus St 1342, L. delbrueckii ssp. bulgaricus Lb 1466, L. acidophilus strains (La 4962 and L10) and L. casei L26 being higher than that of Bifidobacterium spp. at $24 \mathrm{~h}$ of fermentation.

\subsection{Cell growth and organic acids production}

The change of cell concentration of selected dairy $\mathrm{LAB}$ and probiotic organisms cultivated individually in RSM for $24 \mathrm{~h}$ at $42{ }^{\circ} \mathrm{C}$ is shown in Figure 3. Lactic acid bacteria are nutritionally fastidious organisms which require more free amino acids or peptides than present in milk. Thus proteolytic activity is important requirement for achieving a minimum level of $10^{6}$ to $10^{7} \mathrm{CFU} \cdot \mathrm{mL}^{-1}$ of active probiotics in a product to observe positive health effect $[36,44]$. In general, examined probiotic cultures achieved the desired therapeutic 


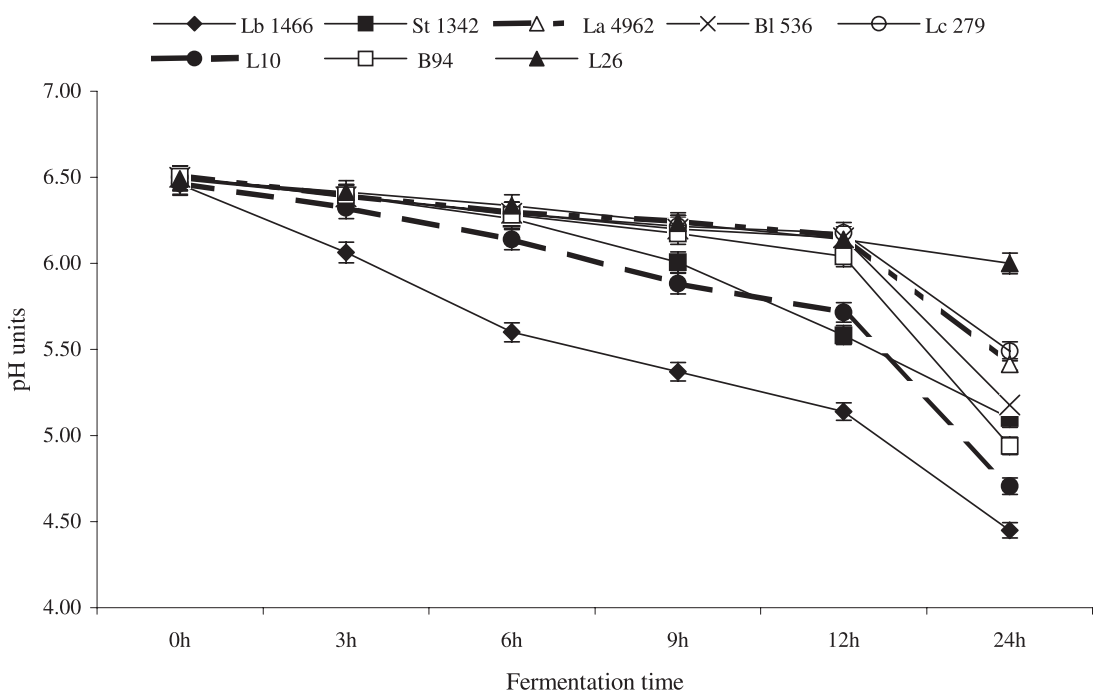

Figure 4. $\mathrm{pH}$ changes during fermentation of single strains in RSM by S. thermophilus St 1342, L. belbrueckii subsp. bulgaricus Lb 1466, L. acidophilus L10, B. lactis B94 and L. casei L26, L. acidophilus La 4962, B. longum B1 536 and L. casei Lc 279 (Error bars present a pooled standard error of the mean).

level $\left(10^{8} \mathrm{CFU} \cdot \mathrm{mL}^{-1}\right)$ during their growth in RSM after $24 \mathrm{~h}$ (Fig. 3). Although the cultures showed a consistent increase in cell concentration until $9 \mathrm{~h}$, the required $\mathrm{pH}$ of 4.5 was not reached as shown in Figure 4. Sodini et al. [42] also reported that individual probiotic cultures grew well in fermented milk and did not produce organic acids as fast as with mixed starter cultures. Lactobacillus acidophilus La 4962 and L. casei Lc 279 experienced a superior growth $(P<0.05)$ as compared to other probiotic organisms. On the other hand, B. lactis B94 and B. longum B1 536 showed slow growth pattern and no significant $(P>0.05)$ difference in the cell counts was observed (Fig. 3). S. thermophilus St 1342 achieved a significantly $(P<0.05)$ higher cell concentration in comparison to L. delbrueckii ssp. bulgaricus Lb 1466; the slow growth of the latter resulted in low viability $\left(10^{7} \mathrm{CFU} \cdot \mathrm{mL}^{-1}\right)$ at the end of the fermentation period of $20 \mathrm{~h}$.

Eventhough L. delbrueckii ssp. bulgaricus Lb 1466 grew slowly in RSM, it produced substantial amount of lactic acid, second to S. thermophilus St 1342 (Fig. 5), and the highest $(P<0.05)$ decline in $\mathrm{pH}$ at the end of fermentation (Fig. 4). As previously observed by Donkor et al. [13], the yoghurt culture (S. thermophilus and L. delbrueckii ssp. bulgaricus) produced substantially more lactic acid than any other strain in the study. However, the study also showed that probiotic organisms produced some lactic acid even though not as high as in the case of yoghurt culture, with $L$. acidophilus L10 producing the highest and L. case i L26 the lowest concentration (Fig. 5).

In general, the production of acetic acid as presented in Figure 6 was fairly uniform in each batch of fermented milk up to $12 \mathrm{~h}$. All cultures produced a substantial $(P<0.05)$ amount of acetic acid except $L$. acidophilus L10 (Fig. 6). Lactobacillus casei Lc 279 on the other hand, produced significantly $(P<0.05)$ higher acetic acid than other probiotics. The upsurge in cell growth for all batches from $9 \mathrm{~h}$ to $24 \mathrm{~h}$ (Fig. 3 ) resulted in significant $(P<0.05)$ increases in the concentration of organic acids and decline in $\mathrm{pH}$ (Fig. 4) but the concentration of 


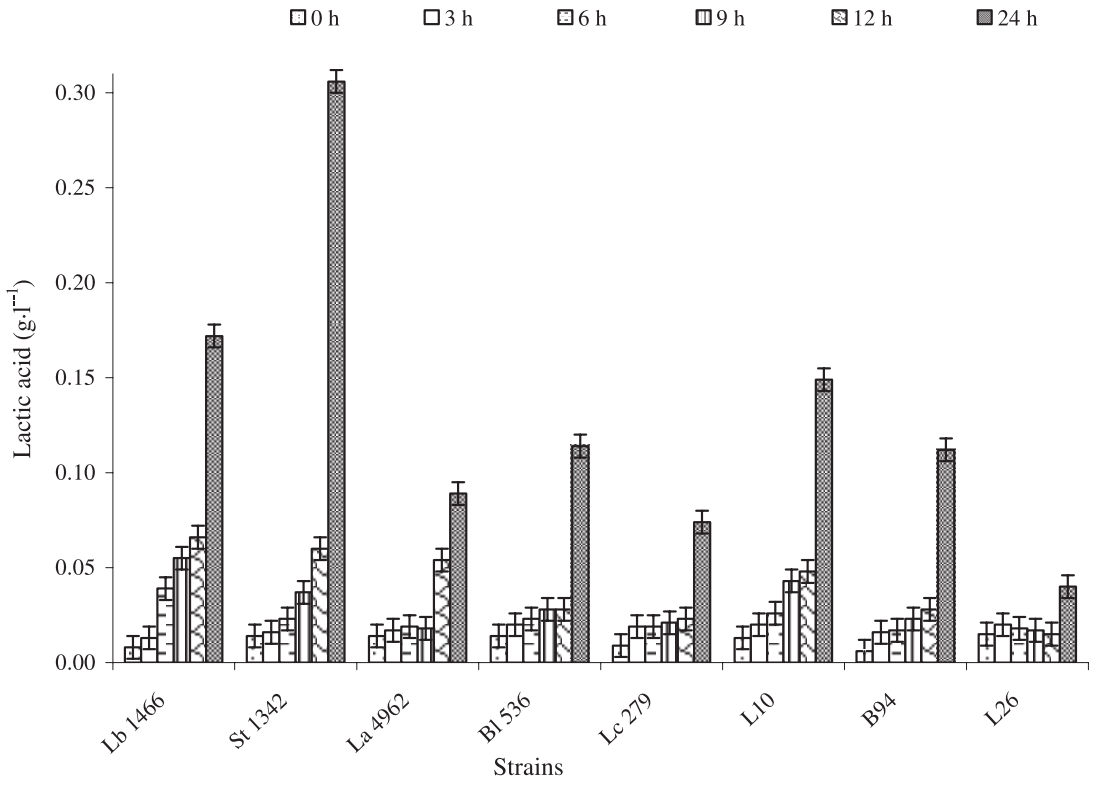

Figure 5. Production of lactic acid during fermentation of single strains in RSM for $24 \mathrm{~h}$ at $42{ }^{\circ} \mathrm{C}$ by S. thermophilus St 1342, L. belbrueckii subsp. bulgaricus Lb 1466, L. acidophilus L10, B. lactis B94 and L. casei L26, L. acidophilus La 4962, B. longum B1 536 and L. casei Lc 279 (Error bars represent a pooled standard error of the mean $\mathrm{SEM}=0.01 \mathrm{~g} \cdot \mathrm{L}^{-1}$ ).

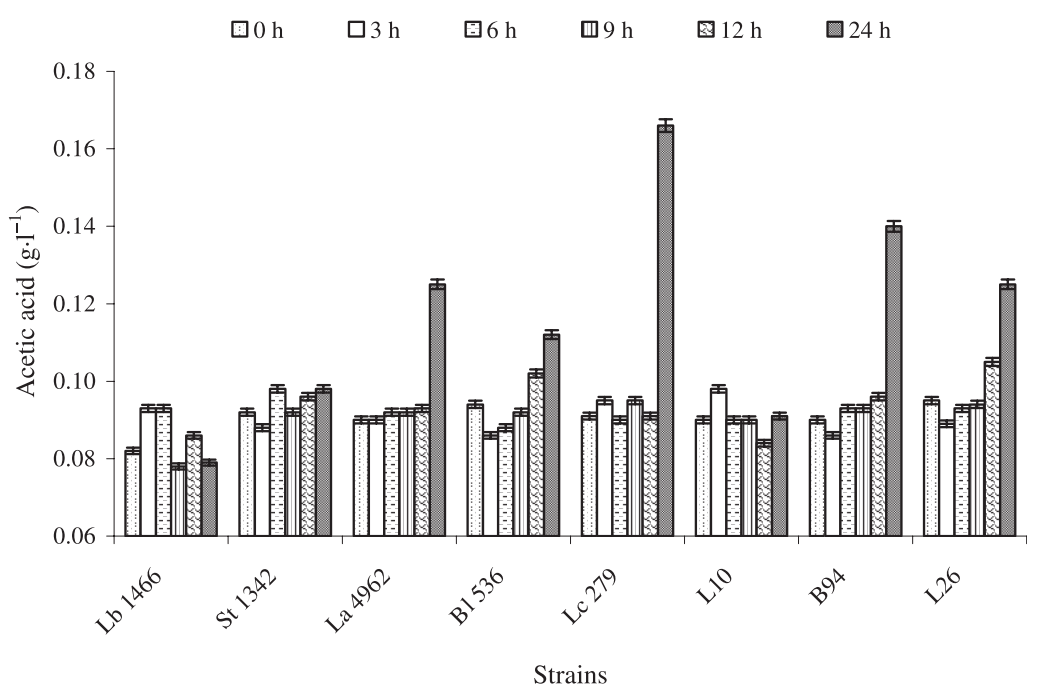

Figure 6. Production of acetic acid in fermented milk by S. thermophilus St 1342, L. delbrueckii subsp. bulgaricus Lb 1466, L. acidophilus L10, B. lactis B94 and L. casei L26, L. acidophilus La 4962, B. longum B1 536 and L. casei Lc 279 during $24 \mathrm{~h}$ fermentation of RSM at $42{ }^{\circ} \mathrm{C}$ (Error bars represent a pooled standard error of the mean SEM $=0.01 \mathrm{~g} \cdot \mathrm{L}^{-1}$ ). 
Table IV. Angiotensin I-converting enzyme (ACE) inhibitory of fermented milk extracts obtained after $24 \mathrm{~h}$ of individual culture fermentations in RSM at $42{ }^{\circ} \mathrm{C}$.

\begin{tabular}{lcc}
\hline $\begin{array}{l}\text { In vitro ACE-inhibitor activity } \\
\text { Culture }\end{array}$ & 24 h inhibition, $\%$ & $\mathrm{IC}_{50^{*}}, \mathrm{mg} \cdot \mathrm{mL}^{-1}$ \\
\hline S. thermophilus St 1342 & $43.65 \pm 4.67$ & $0.225 \pm 0.033$ \\
L. delbrueckii ssp. bulgaricus & $51.10 \pm 2.30$ & $0.187 \pm 0.012$ \\
Lb 1466 & & \\
L. acidophilus $\mathrm{L} 10$ & $62.55 \pm 0.24^{\mathrm{A}}$ & $0.151 \pm 0.001^{\mathrm{A}}$ \\
L. acidophilus La 4962 & $53.58 \pm 1.73^{\mathrm{B}}$ & $0.164 \pm 0.007^{\mathrm{B}}$ \\
B. lactis $\mathrm{B} 94$ & $51.64 \pm 3.63^{\mathrm{A}}$ & $0.175 \pm 0.016^{\mathrm{A}}$ \\
B. longum $\mathrm{B} 1536$ & $63.73 \pm 1.71^{\mathrm{B}}$ & $0.196 \pm 0.007^{\mathrm{A}}$ \\
L. paracasei $\mathrm{L} 26$ & $54.02 \pm 1.71^{\mathrm{A}}$ & $0.196 \pm 0.008^{\mathrm{A}}$ \\
L. casei $\mathrm{Lc}$ 279 & $41.15 \pm 4.13^{\mathrm{B}}$ & $0.344 \pm 0.053^{\mathrm{B}}$ \\
\hline
\end{tabular}

* The activity is expressed as the concentration of peptides in $\mathrm{mg} \cdot \mathrm{mL}^{-1}$ required to inhibit $50 \%$ of the original ACE activity $\left(\mathrm{IC}_{50}\right)$.

$\mathrm{AB}$ Means in the same column for particular strains with different capital letter superscripts are significantly different.

organic acids attained did not affect the cell growth as noted in other studies $[1,36,42]$. The organisms appeared to have maintained appreciable cell counts during the $24 \mathrm{~h}$ fermentation in RSM possibly due to efficient proteolytic systems [19].

\subsection{ACE-inhibitory activity}

In our study, eight strains of LAB were cultured individually in RSM to produce fermented milk with in vitro ACE-inhibitory activity shown in Table IV. The results indicate that the production of ACE inhibitors was not confined to a single species or strains of bacteria but all the strains tested produced peptides, which showed in vitro ACE-inhibitory activity. However, un-inoculated RSM did not show ACE-I activity (data not shown). Furthermore, these selected microorganisms showed X-prolyldipeptidyl aminopeptidase activity, which was able to cleave proline-containing sequences (Fig. 1). This may mean that specific peptides could be produced by cleaving N-terminal of X-Pro dipeptides from tri- and oligopeptides which may show ACE-I activity [21]. The activity of the fermented milk obtained for the selected LAB was also compared by determining the protein concentration needed to inhibit
$50 \%$ of the original ACE activity $\left(\mathrm{IC}_{50}\right)$ (Tab. IV). There was a significant $(P<0.05)$ difference in $\mathrm{IC}_{50}$ values between the bacterial strains, indicating possible differences in the quality of ACE-inhibitory peptides produced by the organisms. B. longum $\mathrm{Bl} 536$ and L. acidophilus L10 produced the highest activity at $63.7 \%$ and $62.6 \%$ with $\mathrm{IC}_{50}$ values of 0.196 and 0.151 $\mathrm{mg} \cdot \mathrm{mL}^{-1}$, respectively. Similar results were reported by Pihlanto-Leppalla et al. [31] using different lactic acid staters and digestive enzymes to obtain inhibition of 35 to $86 \%$ and $\mathrm{IC}_{50}$ values between 0.080 to $0.314 \mathrm{mg} \cdot \mathrm{mL}^{-1}$. Several milk protein- derived peptides produced by the enzymatic hydrolysis [33] or by the fermentation of milk with different strains of organisms $[18,23]$ inhibited the activity of ACE.

Although the proteolytic activity of B. longum $\mathrm{B} 1536$ was not as high as L. case $i$ L26, the peptides released by $B$. longum B1 536 had higher ACE-inhibitory activity than those of L. casei L26 (Tab. IV). Fuglsang et al. [17] found that most LAB produced ACE inhibitors in varying amounts during milk fermentation which varied with strains. Their study was in line with our findings which showed a similar trend using selected strains of bacteria and 
further reported that only L. helveticus produced such substances in amounts large enough to cause a direct effect on ACE in vivo out of several strains used. The time-dependent release of various peptides observed in our study might have important consequences on the extent of in vitro $\mathrm{ACE}$ inhibitory activity in fermented milk, which deserves further elaboration.

\section{CONCLUSION}

Selected cultures of $S$. thermophilus St 1342, L. delbrueckii ssp. bulgaricus Lb 1466, L. acidophilus L10, B. lactis B94, L. casei L26, L. acidophilus La 4962, B. longum $\mathrm{Bl} 536$ and L. casei Lc 279 were capable of growing in milk likely due to degradation of milk proteins. Thus, this study has shown that for active and rapid growth in milk, dairy cultures may rely on their proteolytic system. The cultures possessed proteolytic enzymes - proteinases, peptidases and aminopeptidases at extracellular and intracellular levels which showed specific activities toward certain substrates. All strains exhibited X-prolyldipeptidyl aminopeptidase activity cleaving proline-containing sequences. The proteolytic systems including X-prolyl-dipeptidyl aminopeptidase activity of the bacteria strains in RSM resulted in the release of free amino groups and peptides which substantially improved growth and maintained viability in the medium. The proteolytic activity did not appear as the governing factor of growth for Lactobacillus delbrueckii ssp. bulgaricus, which might require additional growth factors. All selected strains produced a range of bioactive peptides with varying degree of ACE-inhibition. B. longum B1 536 and L. acidophilus L10 produced the highest activity $\mathrm{IC}_{50}$ values of 0.196 and $0.151 \mathrm{mg} \cdot \mathrm{mL}^{-1}$, respectively. ACE-I was strain and apparently time dependent.

Acknowledgments: This research was funded by the Australian Research Council (ARC) Linkage grant. The financial contribution by DSM Food Specialties (Moorebank, NSW, Australia) is also gratefully acknowledged.

\section{REFERENCES}

[1] Akalin A.S., Fenderya S., Akbulut N., Viability and activity of bifidobacteria in yoghurt containing fructooligosaccharids during refrigerated storage, Int. J. Food Sci. 39 (2004) 613-621.

[2] Blanc B., Laloi P., Atlan D., Gilbert C., Portalier R., Two cell-wall-associated aminopeptidases from Lactobacillus helveticus and the purification and characterization of APII from strain ITGL1, J. Gen. Microbiol. 139 (1993) 1441-1448.

[3] Bradford M.M., A rapid and sensitive method for the quantitation of microgram quantities of protein utilizing the principle of protein-dye binding, Anal. Biochem. 72 (1976) 248-254.

[4] Christensen J.E., Steele J.L., Impaired growth rates in milk of Lactobacillus helveticus peptidase mutants can be overcome by use of amino acid supplements, J. Bacteriol. 185 (2003) 3297-3306.

[5] Christensen J.E., Dudley E.G., Pederson J.A., Steele J.L., Peptidases and amino acid catabolism in lactic acid bacteria, Antonie Leeuwenhoek 76 (1999) 217-246.

[6] Church F.C., Swaisgood H.E., Porter D.H., Catignani G.L., Spectrophotometric assay using o-phthaldialdehyde for determination of proteolysis in milk and isolated milk proteins, J. Dairy Sci. 66 (1983) 1219-1227.

[7] Coolbear T., Pillidge C.J., Crow V.L., The diversity of potential cheese ripening characteristics of lactic acid starter bacteria: resistance to cell lysis and levels and cellular distribution of proteinase activities, Int. Dairy J. 4 (1994) 697-721.

[8] Crittenden R., Bird A.R., Gopal P., Henriksson A., Lee Y.K., Playne M.J., Probiotic research in Australia, New Zealand and the Asia-Pacific Region, Current Pharmaceut. Design 11 (2005) 37-53.

[9] Cushman D.W., Cheung H.S., Spectrophotometric assay and properties of the angiotensin-converting enzyme of rabbit lung, Biochem. Pharmacol. 20 (1971) 1637-1648.

[10] Dave R.I., Shah N.P., Evaluation of media for selective enumeration of Streptococcus thermophilus, Lactobacillus delbrueckii ssp. bulgaricus, Lactobacillus acidophilus, and bifidobacteria, J. Dairy Sci. 79 (1996) 1529_ 1536.

[11] Dave R.I., Shah N.P., Ingredient supplementation effects on viability of probiotic bacteria in yoghurt, J. Dairy Sci. 81 (1998) 28042816. 
[12] Donkor O.N., Henriksson A., Vasiljevic T., Shah N.P., Probiotic strains as starter cultures improve angiotensin-converting enzyme inhibitory activity in soy yoghurt, J. Food Sci. 70 (2005) M375-M381.

[13] Donkor O.N., Henriksson A., Vasiljevic T., Shah N.P., Effect of acidification on the activity of probiotics in yoghurt during cold storage, Int. Dairy J. 16 (2006) 1180-1189.

[14] FAO/WHO, Guidelines for the evaluation of probiotics in food. Report of a joint FAO/ WHO working group on drafting guidelines for the evaluation of probiotics in food, 2002, London ON, Canada.

[15] Fenster K.M., Parkin K.L., Steele J.L., Characterization of a thiol-dependent endopeptidase from Lactobacillus helveticus CNRZ32, J. Bacteriol. (1997) 2529-2533.

[16] Fernandez-Espla M.D., Martin-Hernandez M.C., Fox P.F., Purification and characterization of a prolidase from Lactobacillus casei subsp. casei IFPL 731, Appl. Environ. Microbiol. 63 (1997) 314-316.

[17] Fuglsang A., Rattray F.P., Nilsson D., Nyborg N.C.B., Lactic acid bacteria: inhibition of angiotensin converting enzymes in vitro and in vivo, Antonie Leeuwenhoek 83 (2003) 27-34

[18] Gobbetti M., Ferranti P., Smacchi E., Goffredi F., Addeo F., Production of angiotensin-Iconverting enzyme-inhibitory peptides in fermented milk started by Lactobacillus delbrueckii subsp. bulgaricus SS1 and Lactobacillus lactis subsp. cremoris FT4, Appl. Environ. Microbiol. 66 (2002) 3898-3904.

[19] Juillard V., Le Bars D., Kunji E.R.S., Konings W.N., Gripon J.C., Richard J., Oligopeptides are the main source of nitrogen for Lactococcus lactis during growth in milk, Appl. Environ. Microbiol. 61 (1995) 30243030.

[20] Klaver F.A.M., Kingma F., Weerkcamp A.H., Growth and survival of bifidobacteria in milk, Neth. Milk Dairy J. 47 (1993) 151164.

[21] Kunji E.R.S., Mierau I., Hagting A., Poolman B., Konings W.N., The proteolytic systems of lactic acid bacteria, Antonie Leeuwenhoek 70 (1996) 187-221.

[22] Law J., Haandrikman A., Proteolytic enzymes of lactic acid bacteria, Int. Dairy J. 7 (1997) $1-11$.

[23] Leclerc P.L., Gauthier S.F., Bachelard H., Santure M., Roy D., Antihypertensive activity of casein-enriched milk fermented by Lactobacillus helveticus, Int. Dairy J. 12 (2002) 995-1004.
[24] Littell R.C., Henry P.R., Ammerman C.B., Statistical analysis of repeated measures data using SAS procedures, J. Anim. Sci. 76 (1998) 1216-1231.

[25] Lourens-Hattingh A., Viljoen C.B., Yoghurt as probiotic carrier food, Int. Dairy J. 11 (2001) 1-17.

[26] Mars I., Monnet V., An aminopeptidase P from Lactococcus lactis with original specificity, Biochem. Biophy. Acta 1243 (1995) 209-215.

[27] Nakamura Y., Yamamoto N., Sakai K., Okubo A., Yamazaki S., Takano T., Purification and characterization of angiotensin Iconverting enzyme inhibitors from sour milk, J. Dairy Sci. 78 (1995) 777-783.

[28] Nielsen P.M., Petersen D., Dambmann C., Improved method for determining food protein degree of hydrolysis, J. Food Sci. 66 (2001) 642-646.

[29] Pan D., Luo Y., Tanokura M., Antihypertensive peptides from skimmed milk hydrolysate digested by cell-free extract of Lactobacillus helveticus JCM1004, Food Chem. 91 (2005) 123-129.

[30] Pihlanto A., Korhonen H., Bioactive peptides and proteins, Adv. Food Nutr. Res. 47 (2003) 176-275.

[31] Pihlanto-Leppällä A., Rokka T., Korhonen $\mathrm{H}$, Angiotensin I converting enzyme inhibitory peptides derived from bovine milk proteins, Int. Dairy J. 8 (1998) 325-333.

[32] Ravula R.R., Shah N.P., Selection enumeration of Lactobacillus casei from yoghurts and fermented milk drinks, Biotechnol. Techn. 12 (1998) 819-822.

[33] Roy M.K., Watanabe Y., Tamai Y., Yeast protease B-digested skimmed milk inhibits angiotensin-I-converting-enzyme activity, Biotechnol. Appl. Biochem. 31 (2000) 95100.

[34] SAS, SAS/STAT Software: Changes and enhancements through release 6.11, 1996, SAS Inst. Inc., Cary, NC.

[35] Shah N.P., Effects of milk-derived bioactives: an overview, Br. J. Nutr. 84 (2000) S3S10.

[36] Shah N.P., Probiotic bacteria: Selective enumeration and survival in dairy foods, J. Dairy Sci. 83 (2000) 894-907.

[37] Shah N.P., Some beneficial effects of probiotic bacteria, Biosci. Microflora 19 (2000) 99106.

[38] Shah N.P., Ravula R.R., Influence of water activity on fermentation organic acids production and viability of yoghurt and probiotic 
bacteria, Australian J. Dairy Technol. 55 (2000) 127-131.

[39] Shihata A., Shah N.P., Proteolytic profile of yoghurt and probiotic bacteria, Int. Dairy J. 10 (2000) 401-408.

[40] Skeggs L.T., Kahn J.R., Shumway N.P., The preparation and function of the hypertensionconverting enzyme, J. Exp. Medicine 103 (1956) 295-299.

[41] Smid E.J., Poolmann B., Konings W.N., Casein utilization by lactococci, Appl. Environ. Microbiol. 57 (1991) 2447-2452.

[42] Sodini I., Lucas A., Oliviera M.N., Remeuf F., Corrieu G., Effect of milk base and starter culture on acidification, texture, and probiotic cell counts in fermented milk processing, J. Dairy Sci. 85 (2002) 2479-2488.

[43] Stepaniak L., Fox P.F., Characterization of principal intracellular endopeptidase from Lactococcus lactis subsp. lactis MG1363, Int. Dairy J. 5 (1995) 699-713.

[44] Talwalkar A., Kailasapathy K., A review of oxygen toxicity in probiotic yogurts: Influence on the survival of probiotic bacteria and protective techniques, Rev. Food Sci. Food Safety 3 (2004) 117-124.

[45] Tan P.S.T., Konings W.N., Purification and characterization of aminopeptidase from Lactococcus lactis subsp. cremoris $\mathrm{Wg} 2$, Appl. Environ. Microbiol. 56 (1990) 526532 .
[46] Tan P.S.T., Sasaki M., Bosman B.W., Iwasaki T., Purification and characterization of a dipeptidase from Lactobacillus helveticus SBT 2171, Appl. Environ. Microbiol. 61 (1995) 3430-3435.

[47] Tharmaraj N., Shah N.P., Selective enumeration of Lactobacillus delbrueckii ssp. bulgaricus, Streptococcus thermophilus, Lactobacillus acidophilus, bifidobacteria, Lactobacillus casei, Lactobacillus rhamnosus and Propionibacteria, J. Dairy Sci. 86 (2003) 2288-2296.

[48] Vasiljevic T., Shah N.P., Jelen P., Growth characteristics of Lactobacillus delbrueckii subsp. bulgaricus ATCC 11842 as affected by different neutralizers, Aust. J. Dairy Technol. 60 (2005) 3-9.

[49] Vermeirssen V., Camp J.V., Verstraete W., Optimisation and validation of an angiotensin-converting enzyme inhibition assay for the screening of bioactive peptides, J. Biochem. Biophys. Methods 51 (2002) 75-87.

[50] Wohlrab Y., Bockelmann W., Purification and characterization of a dipeptidase from Lactobacillus delbrueckii subsp. bulgaricus, Int. Dairy J. 2 (1992) 345-361.

[51] Ziemer C.J., Gibson G.R., An overview of probiotics, prebiotics and synbiotics in the functional food concept: perspectives and future strategies, Int. Dairy J. 8 (1998) 473 479. 